\title{
A Methodology for Quantifying Trace Elements in the Exoskeletons of Florida Stone Crab (Menippe mercenaria) Larvae Using Inductively Coupled Plasma Optical Emission Spectrometry (ICP-OES)
}

By Philip M. Gravinese, Jennifer A. Flannery, and Lauren T. Toth

Open-File Report 2016-1148

U.S. Department of the Interior

U.S. Geological Survey 


\title{
U.S. Department of the Interior \\ SALLY JEWELL, Secretary
}

\author{
U.S. Geological Survey \\ Suzette M. Kimball, Director
}

U.S. Geological Survey, Reston, Virginia: 2016

For more information on the USGS-the Federal source for science about the Earth, its natural and living resources, natural hazards, and the environment-visit http://www.usgs.gov/ or call 1-888-ASK-USGS (1-888-275-8747).

For an overview of USGS information products, including maps, imagery, and publications, visit http://store.usgs.gov/.

Any use of trade, firm, or product names is for descriptive purposes only and does not imply endorsement by the U.S. Government.

Although this information product, for the most part, is in the public domain, it also may contain copyrighted materials as noted in the text. Permission to reproduce copyrighted items must be secured from the copyright owner.

Suggested citation:

Gravinese, P.M., Flannery, J.A., and Toth, L.T., 2016, A methodology for quantifying trace elements in the exoskeletons of the Florida stone crab (Menippe mercenaria) larvae using inductively coupled plasma optical emission spectrometry (ICP-OES): U.S. Geological Survey Open-File Report 2016-1148, 12 p., https://doi.org/10.3133/ofr20161148.

ISSN 2331-1258 (online) 


\section{Acknowledgments}

The authors thank lan Enochs and Derek Manzello of the National Oceanic and Atmospheric Administration (NOAA) Atlantic Oceanographic and Meteorological Laboratory for their support in completing this work and Ilsa Kuffner and Julie Richey of the U.S. Geological Survey (USGS) St. Petersburg Coastal and Marine Science Center for discussions that improved this manuscript. This research was funded by a "Protect Our Reefs" grant from Mote Marine Laboratory awarded to Philip Gravinese and Richard Tankersley, both of Florida Institute of Technology. 


\section{Contents}

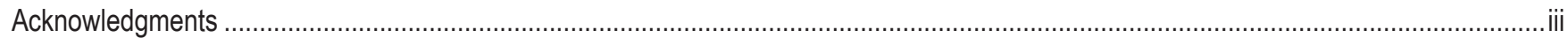

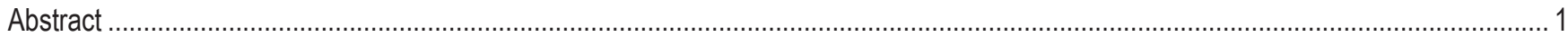

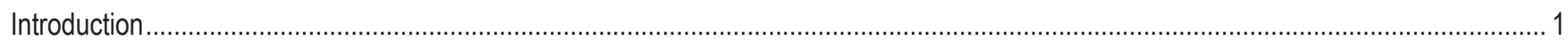

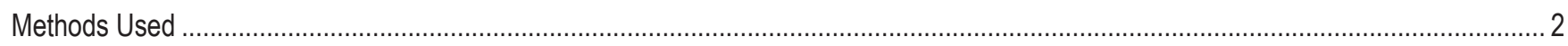

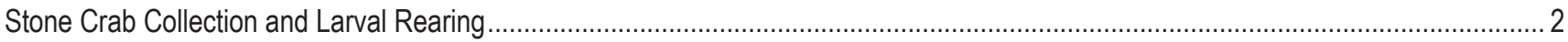

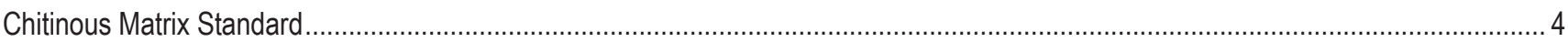

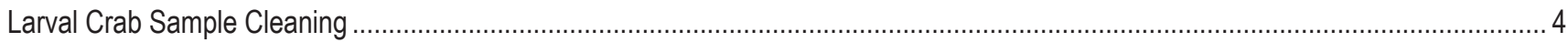

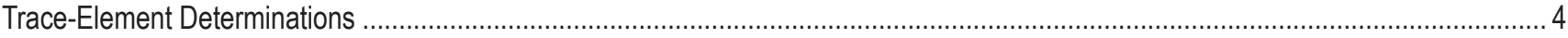

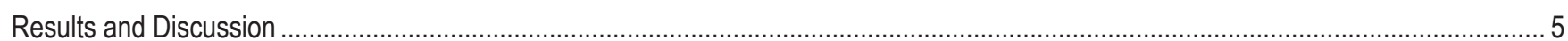

Conclusions

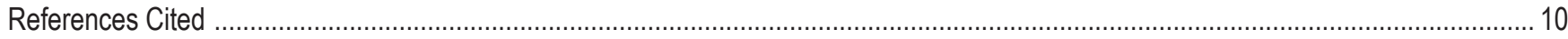

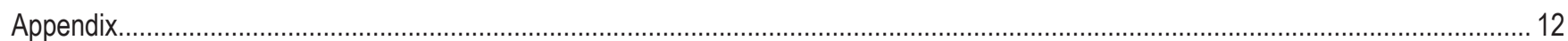

\section{Figures}

1. Scanning electron microscope image of stage III stone crab larvae at $37 x$ magnification ................................................... 3

2. Scanning electron microscope image of stage $V$ stone crab larvae at $37 x$ magnification ..................................................... 3

3. Strontium-to-calcium and magnesium-to-calcium ratios for stage III stone crab larvae from 11 different broods raised at

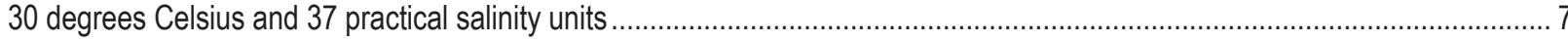

4. Strontium-to-calcium and magnesium-to-calcium ratios for stage $V$ stone crab larvae from 12 different broods raised at

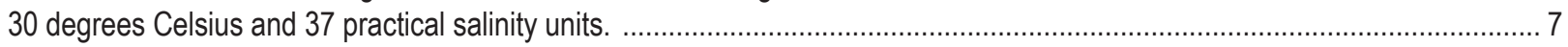

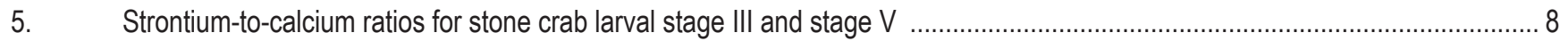

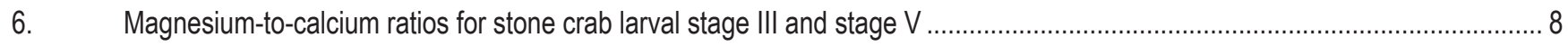

\section{Tables}

1. Average strontium-to-calcium and magnesium-to-calcium values for Menippe mercenaria larval stages III and V and the chitinous matrix standard with associated errors. 


\section{Conversion Factors}

International System of Units to U.S. customary units

\begin{tabular}{ccc}
\hline Multiply & By & To obtain \\
\hline & Length & \\
\hline centimeter $(\mathrm{cm})$ & 0.3937 & inch (in.) \\
millimeter $(\mathrm{mm})$ & 0.03937 & inch (in.) \\
kilometer $(\mathrm{km})$ & 0.6214 & mile (mi) \\
\hline & Volume & ounce, fluid (fl. oz) \\
\hline microliter $(\mu \mathrm{L})$ & $3.38135 \mathrm{e}-05$ & ounce, fluid (fl. oz) \\
milliliter $(\mathrm{mL})$ & 0.034 & ounce, fluid (fl. oz) \\
\hline $\operatorname{liter}(\mathrm{L})$ & 33.82 & \\
\hline & Mass & ounce, avoirdupois (oz)
\end{tabular}

Temperature in degrees Celsius $\left({ }^{\circ} \mathrm{C}\right)$ may be converted to degrees Fahrenheit $\left({ }^{\circ} \mathrm{F}\right)$ as ${ }^{\circ} \mathrm{F}=\left(1.8 \times{ }^{\circ} \mathrm{C}\right)+32$.

\section{Abbreviations}

$\begin{array}{ll}\mathrm{C} & \text { Celsius } \\ \mathrm{Ca} & \text { calcium } \\ \mathrm{CaCO}_{3} & \text { calcium carbonate } \\ \mathrm{H}_{2} \mathrm{O}_{2} & \text { hydrogen peroxide } \\ \mathrm{HNO}_{3} & \text { nitric acid } \\ \mathrm{ICP}-O E S^{-O} & \text { Inductively coupled plasma optical emission spectrometry } \\ \text { IGS } & \text { internal gravimetric standard } \\ \mathrm{M} & \text { molarity } \\ \mathrm{Mg} & \text { magnesium } \\ \mathrm{mmol} \text { mol-1 } & \text { millimole per mole } \\ \mathrm{NaOH} & \text { sodium hydroxide } \\ \mathrm{NIST} & \text { National Institute of Standards and Technology } \\ \mathrm{N} & \text { normal } \\ \text { ppm } & \text { parts per million } \\ \text { psu } & \text { practical salinity units } \\ \mathrm{RPM} & \text { revolutions per minute } \\ \mathrm{RSD} & \text { relative standard deviation } \\ \mathrm{SEM} & \text { scanning electron microscope } \\ \mathrm{Sr} & \text { strontium } \\ \text { USGS } & \text { U.S. Geological Survey } \\ \mathrm{V} & \text { volume }\end{array}$




\title{
A Methodology for Quantifying Trace Elements in the Exoskeletons of Florida Stone Crab (Menippe mercenaria) Larvae Using Inductively Coupled Plasma Optical Emission Spectrometry (ICP-OES)
}

\author{
By Philip M. Gravinese, ${ }^{1}$ Jennifer A. Flannery, ${ }^{2}$ and Lauren T. Toth ${ }^{2}$
}

\section{Abstract}

The larvae of the Florida stone crab, Menippe mercenaria, migrate through a variety of habitats as they develop and, therefore, experience a broad range of environmental conditions through ontogeny. Environmental variability experienced by the larvae may result in distinct elemental signatures within the exoskeletons, which could provide a tool for tracking the environmental history of larval stone crab populations. A method was developed to examine trace-element ratios, specifically magnesium-tocalcium $(\mathrm{Mg} / \mathrm{Ca})$ and strontium-to-calcium $(\mathrm{Sr} / \mathrm{Ca})$ ratios, in the exoskeletons of $M$. mercenaria larvae. Two developmental stages of stone crab larvae were analyzed-stage III and stage V. Specimens were reared in a laboratory environment under stable conditions to quantify the average ratios of $\mathrm{Mg} / \mathrm{Ca}$ and $\mathrm{Sr} / \mathrm{Ca}$ of larval stone crab exoskeletons and to determine if the ratios differed through ontogeny. The elemental compositions $(\mathrm{Ca}, \mathrm{Mg}$, and $\mathrm{Sr})$ in samples of stage III larvae $(\mathrm{n}=50$ per sample) from 11 different broods (mean $\mathrm{Sr} / \mathrm{Ca}=5.916 \pm 0.161$ millimole per mole $\left[\mathrm{mmol} \mathrm{mol}^{-1}\right]$; mean $\mathrm{Mg} / \mathrm{Ca}=$ $\left.218.275 \pm 59.957 \mathrm{mmol} \mathrm{mol}^{-1}\right)$ and stage $\mathrm{V}$ larvae $(\mathrm{n}=10$ per sample) from 12 different broods (mean $\mathrm{Sr} / \mathrm{Ca}=6.110 \pm 0.300 \mathrm{mmol} \mathrm{mol}^{-1}$; mean $\mathrm{Mg} / \mathrm{Ca}=267.081 \pm 67.211 \mathrm{mmol} \mathrm{mol}^{-1}$ ) were measured using inductively coupled plasma optical emission spectrometry (ICP-OES). The ratio of Sr/Ca significantly increased from stage III to stage V larvae, suggesting an ontogenic shift in $\mathrm{Sr} / \mathrm{Ca}$ ratios between larval stages. The ratio of $\mathrm{Mg} / \mathrm{Ca}$ did not change significantly between larval stages, but variability among broods was high. The method used to examine the trace-element ratios provided robust, highly reproducible estimates of $\mathrm{Sr} / \mathrm{Ca}$ and $\mathrm{Mg} / \mathrm{Ca}$ ratios in the larvae of $M$. mercenaria, demonstrating that ICP-OES can be used to determine the trace-element composition of chitinous organisms like the Florida stone crab.

\section{Introduction}

Benthic coastal crustaceans brood their embryos for several weeks before larvae hatch. Upon hatching, planktonic larvae are released into the water column where behavioral responses to certain environmental cues will help facilitate dispersal (Dibacco and Levin, 2000). The specific dispersal strategy of a given species is dependent on how the species synchronizes the timing of larval release with certain environmental cues (for example, tidal cues) and (or) if the larvae can regulate their vertical position throughout ontogeny (that is, endogenous or exogenous responses to environmental stimuli). Synchronic behaviors, such as larval release and vertical swimming, to certain environmental stimuli advect larvae away from parent populations where visual predators are abundant and transport larvae to habitats where conditions are more favorable for continuing development (Sulkin, 1984). As a result, larvae are

'Florida Institute of Technology

${ }^{2}$ U.S. Geological Survey 
exposed to a wide range of environmental conditions through ontogeny (Dibacco and Levin, 2000), which may drive shifts in the elemental composition of their exoskeletons. Quantifying trace-element composition within larval exoskeletons could, therefore, be useful in tracking the environmental history of marine larvae among different populations (Anastasia and others, 1998).

The Florida stone crab, Menippe mercenaria, inhabits nearshore, subtidal coastal habitats from North Carolina to Texas, with isolated populations occurring throughout the Caribbean. Stone crabs support an important commercial fishery throughout the Southeastern United States. For example, in Florida, commercial stone crab fisheries contribute approximately \$25 million per year to the local economy (Florida Fish and Wildlife Conservation Commission, undated) and this estimate does not account for active, recreational stone crab fisheries within the region. During the summer reproductive season, stone crabs brood larvae on their abdomen for about 2 weeks before larval release. Larval release occurs on a diel cycle and can be synchronized with tidal cues in some areas (Krimsky and others, 2009). Like most other brachyuran crabs, stone crabs release their larvae in nearshore coastal habitats, but the larvae are immediately transported to offshore areas where they complete larval development. Larval development takes about 28 days and consists of five planktonic larval stages and one post-larval (meglopae) stage, after which individuals recruit back into nearshore environments (Porter, 1960; Mootz and Epifanio, 1974).

The purpose of this study was to develop a method to efficiently quantify trace-element ratios, specifically magnesium to calcium $(\mathrm{Mg} / \mathrm{Ca})$, in the stage III and stage $\mathrm{V}$ exoskeletons of $M$. mercenaria larvae (figs. 1 and 2, respectively). The exoskeleton of newly hatched crustacean larvae are lightly mineralized (Whiteley, 2011); therefore, we analyzed the exoskeletons of mid- to late-stage stone crab larvae (stages III and V), which are primarily built of high-Mg calcite (Ries and others, 2009; Ries 2011). Our goals were to quantify a baseline estimate of $\mathrm{Mg} / \mathrm{Ca}$ and $\mathrm{Sr} / \mathrm{Ca}$ ratios for stone crab larvae reared under controlled laboratory conditions and determine if the elemental composition of their exoskeletons changes through development (that is, from stage III to stage V).

\section{Methods Used}

\section{Stone Crab Collection and Larval Rearing}

Ovigerous female M. mercenaria were collected by the Florida Fish and Wildlife Conservation Commission using commercial stone crab traps located 17 kilometers from the Everglades coast in Florida Bay. Newly hatched larvae from each female were transferred into separate experimental rearing chambers (modified plastic containers; 18.9 liters). Each container was kept in its own water bath to maintain temperatures within a narrow range $\left(30.0 \pm 0.23\right.$ degrees Celsius $\left({ }^{\circ} \mathrm{C}\right)[$ mean \pm standard deviation]). Salinity was also maintained within a narrow range (37.7 \pm 0.47 practical salinity units [psu]). Each day, larvae were fed 0.5 per milliliter $\left(\mathrm{mL}^{-1}\right)$ Artemia spp. (brine shrimp) enriched with self-emulsifying lipid concentrate (SELCO) and rotifers (Rotigrow ${ }^{\circledR}$ Onestep). Larvae were kept on a 14-hourslight to 10-hours-dark photoperiod that approximated natural conditions during the time of collection. To minimize buildup of nutrients, dead larvae and wastes were removed from each chamber twice daily. Samples were harvested from the experimental rearing chambers when larvae reached stage III $(n=50$ larvae) and stage V ( $\mathrm{n}=10$ larvae) of development (figs. 1 and 2; based on the descriptions of Porter, 1960). The larval samples were flash frozen using liquid nitrogen and kept at $-80{ }^{\circ} \mathrm{C}$ until they were prepared for trace-element analysis. 


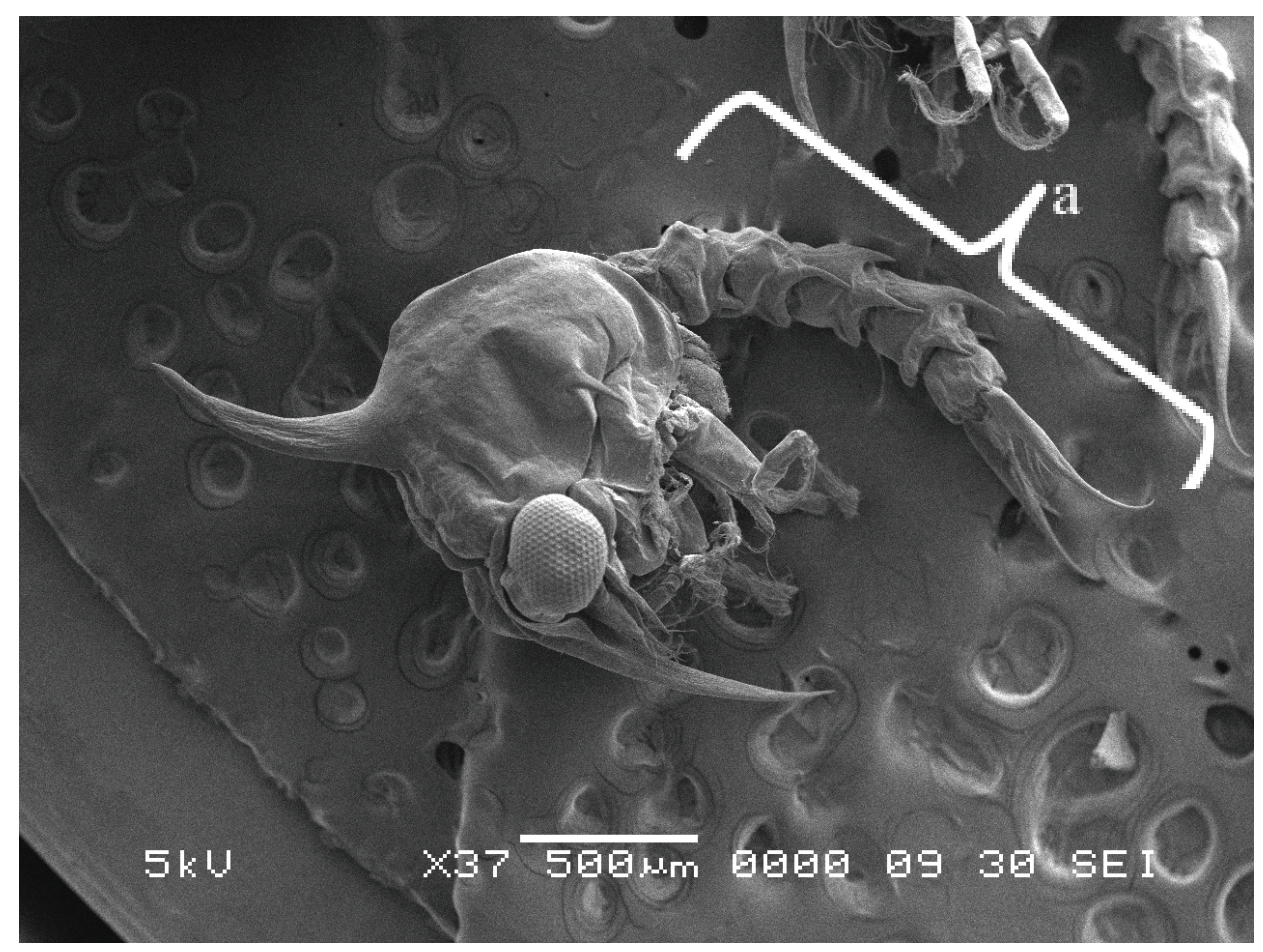

Figure 1. Scanning electron microscope (SEM) image of stage III stone crab larvae at 37x magnification. According to Porter (1960), stage III stone crab larvae can be identified by the presence of a sixth abdominal segment (labeled as "a"), whereas stage II larvae only have five abdominal segments.

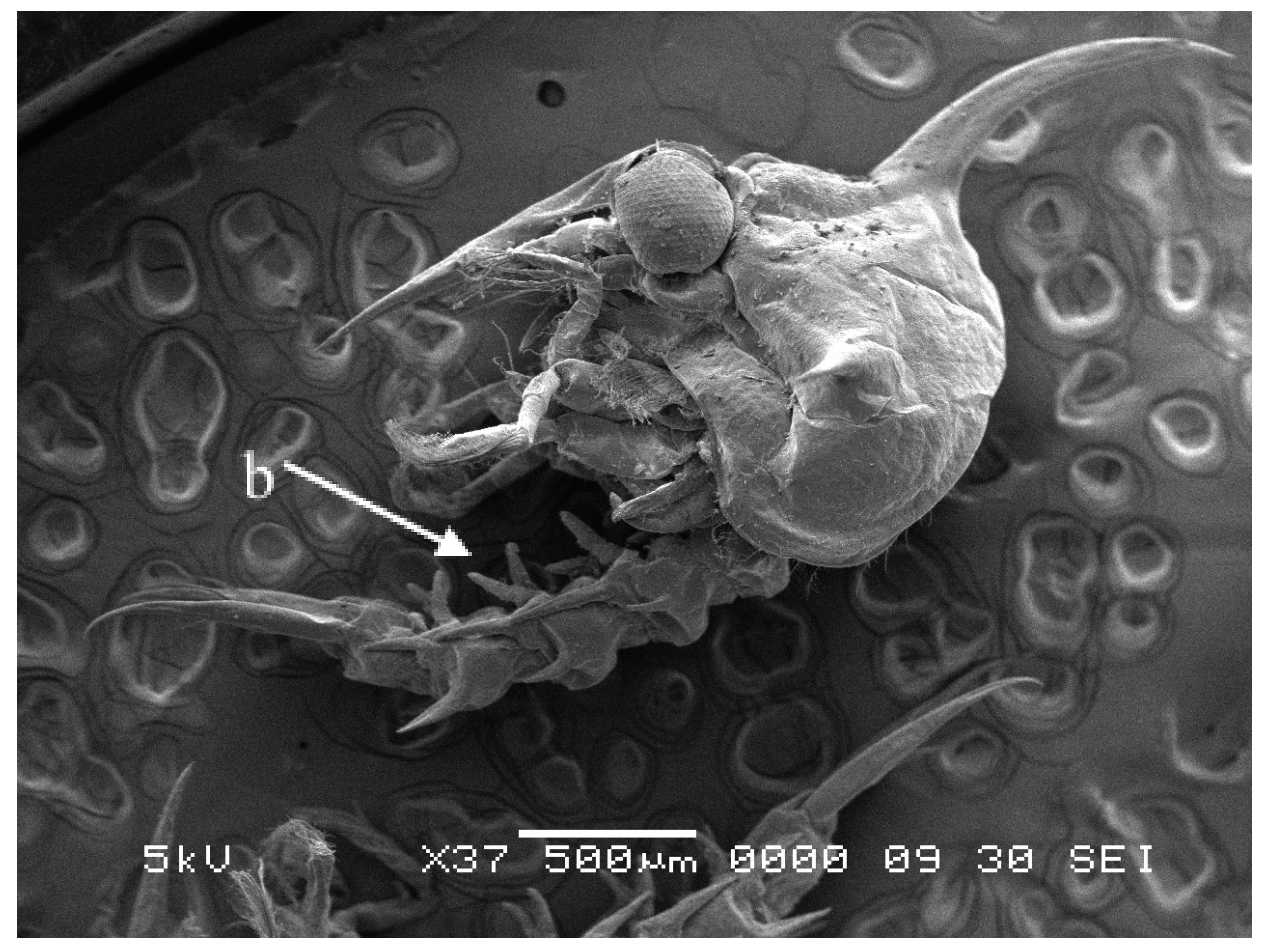

Figure 2. Scanning electron microscope (SEM) image of stage $V$ stone crab larvae at $37 x$ magnification. According to Porter (1960), stage V stone crab larvae can be identified by the presence of dorsal and rostral spines that are three times the size of the lateral spines (observed prior to placement on the SEM stub). Additionally, the first four abdominal segments contain elongated pleopods (labeled as "b"). 


\section{Chitinous Matrix Standard}

To our knowledge, no laboratory/instrument matrix standard for crab samples currently exists for elemental (that is, calcium [Ca], strontium [Sr], and magnesium [Mg]) analyses. It is important to have a standard with a similar elemental matrix as the unknown samples; therefore, we created a matrix standard using the chitinous exoskeleton (that is, a claw) of an adult M. mercenaria. Soft tissues were physically removed from the claw exoskeleton by using tweezers and a scalpel, and the remaining exoskeletal material was sonicated in 30 percent trace-metal-grade hydrogen peroxide $\left(\mathrm{H}_{2} \mathrm{O}_{2}\right)$ for 20 minutes to remove any organic material. This was followed by sonication in type- 2 analytical water to remove any remaining $\mathrm{H}_{2} \mathrm{O}_{2}$ and (or) particulate material. The remaining claw material was pulverized with a mortar and pestle to obtain a fine white powder. An aqueous stock solution of the standard was created by adding 0.5 gram $(\mathrm{g})$ of the pulverized powder to 1,000 milliliters $(\mathrm{mL})$ of 2 percent nitric acid $\left(\mathrm{HNO}_{3}\right)$ and sonicated in a water bath at $80{ }^{\circ} \mathrm{C}$ for an hour to fully dissolve all of the calcium carbonate $\left(\mathrm{CaCO}_{3}\right)$ within the exoskeleton. This procedure yielded a concentration of 1,000 parts per million (ppm) $\mathrm{Ca}$ in the solution. An aqueous working standard solution was created by diluting the stock solution to a concentration of $20 \mathrm{ppm}$ on the basis of the solution's molarity (M) and volume (V) using the formula

$$
\mathrm{M}_{1} \mathrm{~V}_{1}=\mathrm{M}_{2} \mathrm{~V}_{2}
$$

\section{Larval Crab Sample Cleaning}

Estimates of trace-metal concentrations were determined by analyzing samples of stage III ( $\mathrm{n}=$ $50)$ and stage $V$ larvae $(n=10)$ from unique female broods $(n=11$ and $n=12$, respectively). Prior to analysis, each sample of larvae underwent an oxidation cleaning treatment to remove any organic material within the exoskeleton by using a modified procedure developed for oxidizing planktonic foraminifera tests (Russell and others, 2004). Each sample was cleaned three times using hot-buffered hydrogen peroxide (1:1 solution of 0.1 normal [N] sodium hydroxide $[\mathrm{NaOH}]$ and 30 percent $\left.\mathrm{H}_{2} \mathrm{O}_{2}\right)$ held at $80{ }^{\circ} \mathrm{C}$ for 30 minutes and rinsed five times with type-2 analytical water. All samples were cleaned and analyzed at the U.S. Geological Survey Coastal and Marine Science Center in St. Petersburg, Fla.

\section{Trace-Element Determinations}

Once each larval-crab sample was cleaned and oxidized, 100 microliters $(\mu \mathrm{L})$ of concentrated trace-metal-grade 70 percent nitric acid $\left(\mathrm{HNO}_{3}, 16\right.$ molar [M]) was added to each sample. Acidified samples underwent sonication in a hot water bath for 15 minutes to fully dissolve all $\mathrm{CaCO}_{3}$ into aqueous solution. Samples were then centrifuged at 7,000 revolutions per minute (RPM) for 5 minutes to drive any remaining organic/non-soluble material to the bottom of the vial. Seventy $\mu \mathrm{L}$ of 70 percent $\mathrm{HNO}_{3}$ liquid containing dissolved $\mathrm{CaCO}_{3}$ was transferred into a $17 \mathrm{~mL}$ test tube and was diluted with $2.45 \mathrm{~mL}$ of type-2 analytical water to bring each liquid sample concentration to 2 percent $\mathrm{HNO}_{3}$ $(0.45 \mathrm{M})$, consistent with the $\mathrm{HNO}_{3}$ concentration of all analytical standards used.

A PerkinElmer 7300 dual view ICP-OES was used to measure the elemental composition of $\mathrm{Ca}, \mathrm{Sr}$, and $\mathrm{Mg}$. At the beginning of each run, the machine was calibrated using a mixture of PlasmaCal (traceable to the National Institute of Standards and Technology [NIST] factory standards) with a Sr/Ca ratio of 0.00795 (3.635 millimole per mole $\left[\mathrm{mmol} \mathrm{mol}^{-1}\right]$ ) and a $\mathrm{Mg} / \mathrm{Ca}$ ratio of 0.12915 (212.916 $\left.\mathrm{mmol} \mathrm{mol}^{-1}\right)$ with calcium concentrations at 8, 20, 30, and $40 \mathrm{ppm}$. A test run on the ICP-OES (using $\sim 1 \mathrm{~mL}$ of aqueous solution) was used to estimate the Ca concentrations of each larval-crab 
sample and, if necessary, 2 percent $\mathrm{HNO}_{3}$ was used to dilute each sample to a target $\mathrm{Ca}$ concentration of $20 \mathrm{ppm}$ (the concentration yielding the highest linear calibration on the instrument). The full run on the instrument had an internal gravimetric standard (IGS) run before and after every sample. The IGS solution was also prepared from single-element PlasmaCal solutions with a $20 \mathrm{ppm} \mathrm{Ca}$ concentration and $\mathrm{Sr} / \mathrm{Ca}$ ratios of $0.00790511\left(3.61 \mathrm{mmol} \mathrm{mol}^{-1}\right)$ and $\mathrm{Mg} / \mathrm{Ca}$ ratios of 0.12804106 (211.145 $\left.\mathrm{mmol} \mathrm{mol}^{-1}\right)$. IGS statistics were computed for every run, and the runs were accepted if the relative standard deviation (RSD, $1 \sigma$ standard deviation/average) for the IGS solution was $<0.2$ percent for $\mathrm{Sr} / \mathrm{Ca}$ and $<1.5$ percent for $\mathrm{Mg} / \mathrm{Ca}$. The chitinous matrix standard (see above section) was run every five samples to test for any potential matrix effects caused by small-scale variability in the composition of the chitinous exoskeleton. Ratios of $\mathrm{Sr} / \mathrm{Ca}$ and $\mathrm{Mg} / \mathrm{Ca}$ were corrected for instrumental drift and noise following the IGS method devised by Schrag (1999). The average corrected IGS precision for $\mathrm{Sr} / \mathrm{Ca}$ was $0.0030 \mathrm{mmol}$ $\mathrm{mol}^{-1}(0.08$ percent, $1 \sigma, \mathrm{n}=35)$ and $\mathrm{Mg} / \mathrm{Ca}$ was $1.739 \mathrm{mmol} \mathrm{mol}^{-1}(0.81$ percent, $1 \sigma, \mathrm{n}=35)$. The matrix standard had an average corrected precision of $\mathrm{Sr} / \mathrm{Ca} 0.0067 \mathrm{mmol} \mathrm{mol}^{-1}(0.12$ percent, $1 \sigma, \mathrm{n}=56)$ and $\mathrm{Mg} / \mathrm{Ca}$ was $1.473 \mathrm{mmol} \mathrm{mol}^{-1}(1.04$ percent, $1 \sigma, \mathrm{n}=56) . \mathrm{Sr} / \mathrm{Ca}$ and $\mathrm{Mg} / \mathrm{Ca}$ values were accepted if they ranged from 10 to $30 \mathrm{ppm}$ Ca concentration. Ratios were converted to millimole per mole using the formula

$\mathrm{R}_{\mathrm{mmol} / \mathrm{mol}}=\mathrm{r}^{*}($ molar mass of calcium $(40.078) /$ molar mass of metal $(\mathrm{Sr}=87.62 ; \mathrm{Mg}=24.305) * 1,000$.

The $\mathrm{Sr} / \mathrm{Ca}$ and $\mathrm{Mg} / \mathrm{Ca}$ ratios of each sample represent average values across the total number of individuals in each sample ( $\mathrm{n}=50$ for stage III and $\mathrm{n}=10$ for stage V) (figs. 3-6).

\section{Results and Discussion}

$\mathrm{Sr} / \mathrm{Ca}$ values were similar among broods (figs. 3 and 4) and between the two larval stages (fig. 5). The average $\mathrm{Sr} / \mathrm{Ca}$ values for all stage III and stage V larvae were $5.916 \pm 0.161 \mathrm{mmol} \mathrm{mol}^{-1}$ and $6.110 \pm 0.300 \mathrm{mmol} \mathrm{mol}^{-1}$, respectively (table 1). Although there was a statistically significant increase in $\mathrm{Sr} / \mathrm{Ca}$ from stage III to stage V (paired t-test: $\mathrm{t}=-2.67, \mathrm{p}=0.028$ ), $\mathrm{Sr} / \mathrm{Ca}$ values were lower $(5.571 \pm 0.007)$ in the adult stone crab exoskeleton that was used to develop the matrix standard. This suggests that there may be ontogenetic shifts in the trace-element concentration of stone crab exoskeletons, but the direction of those shifts may change between larval and adult stages of development.

To our knowledge, no other studies have been conducted to determine the $\mathrm{Sr} / \mathrm{Ca}$ ratio of larval crabs, so direct comparison of our results to published data from other crustaceans is not possible. Instead, we compare the $\mathrm{Sr} / \mathrm{Ca}$ ratios from this study to other well-studied marine calcifiers. Currently [2016], the accepted range of $\mathrm{Sr} / \mathrm{Ca}$ ratios in coral aragonite varies between 8 and $10 \mathrm{mmol} \mathrm{mol}^{-1} \mathrm{de}-$ pending on the coral species (that is, Siderastrea siderea, 8.96-8.99 $\mathrm{mmol} \mathrm{mol}^{-1}$, DeLong and others, 2011; Porites lutea, $9.01 \mathrm{mmol} \mathrm{mol}^{-1}$, Wu and others, 2013, Orbicella faveolata, $9.21 \mathrm{mmol} \mathrm{mol}^{-1}$, Flannery and Poore, 2013; Flannery and others, 2017). Sr/Ca values for biogenic calcite tend to be much lower than values for aragonite (for example, $0.8-1.56 \mathrm{mmol} \mathrm{mol}^{-1}$ in planktic foraminifera, Edgar and others, 2015; $3.5 \mathrm{mmol} \mathrm{mol}^{-1}$ in the coralline red algal species Sporolithon durum, Darrenougue and others, 2014). The carbonate incorporated into the chitinous skeleton of crabs is primarily high-Mg calcite (Ries and others, 2009; Ries, 2011). This may explain why the $\mathrm{Sr} / \mathrm{Ca}$ ratio determined in this study from M. mercenaria larvae fell between the accepted values for biogenic low-Mg calcite and aragonite.

$\mathrm{Mg} / \mathrm{Ca}$ ratios were much more variable than $\mathrm{Sr} / \mathrm{Ca}$ ratios both among broods within each stage (figs. 3 and 4) and between the two stages (fig. 6). The average $\mathrm{Mg} / \mathrm{Ca}$ values for all stage III and stage V larvae were $218.275 \pm 59.957 \mathrm{mmol} \mathrm{mol}^{-1}$ and $267.081 \pm 67.211 \mathrm{mmol} \mathrm{mol}^{-1}$, respectively (table 1 ). 
Because of the high variability among broods, the apparent increase in $\mathrm{Mg} / \mathrm{Ca}$ ratios between stages was not significant (paired t-test: $\mathrm{t}=-1.75, \mathrm{p}=0.118$ ).

These values are slightly higher than previously published values for high-Mg calcite determined for crustose coralline algae Clathromorphum spp. from the Aleutian Islands in the North Pacific Ocean (120-160 mmol mol ${ }^{-1}$, Williams and others, 2014) and from the North Atlantic Ocean ( 132 mmol mol-1, Gamboa and others, 2010), which may be because the coralline algae came from cold-water environments whereas stone crabs live in warmer, subtropical areas. The $\mathrm{Mg} / \mathrm{Ca}$ values determined in this study are lower than $\mathrm{Mg} / \mathrm{Ca}$ values (290-310 $\mathrm{mmol} \mathrm{mol}^{-1}$ ) determined in coralline red algal species Sporolithon durum samples from New Caledonia (Darrenougue and others, 2014), where ocean waters of the South Pacific are warmer than waters near the Florida Keys. As expected, the $\mathrm{Mg} / \mathrm{Ca}$ values from high-Mg calcite $M$. mercenaria larvae are much greater than accepted $\mathrm{Mg} / \mathrm{Ca}$ values of foraminiferal low-Mg calcite, which typically range from $\sim 3$ to $5 \mathrm{mmol} \mathrm{mol}^{-1}$ (that is, $4.4 \mathrm{mmol}$ $\mathrm{mol}^{-1}$, Richey and others, 2007). The $\mathrm{Mg} / \mathrm{Ca}$ values of $M$. mercenaria larvae are also greater than the $\mathrm{Mg} / \mathrm{Ca}$ of the chitinous matrix standard developed in this study. Temperature influences the partitioning of $\mathrm{Mg}$ from seawater into the $\mathrm{CaCO}_{3}$ matrix (Williams and others, 2014) for crustose coralline algae. Because stone crab larvae generally live in the upper portion of the water column, the greater values found in M. mercenaria larvae could reflect warmer water temperatures at the time of growth (controlled at $30{ }^{\circ} \mathrm{C}$ ). Alternatively, the difference between the $\mathrm{Mg} / \mathrm{Ca}$ ratios of the matrix standard and the larval samples could reflect long-term changes in the incorporation of $\mathrm{Mg}$ through ontogeny, but further sampling (replication of adults) would be required to test this hypothesis.

Table 1. Average strontium-to-calcium ( $\mathrm{Sr} / \mathrm{Ca}$ ) and magnesium-to-calcium $(\mathrm{Mg} / \mathrm{Ca})$ values for Menippe mercenaria larval stages III and V and the chitinous matrix standard with associated errors.

$\left[1 \sigma\right.$ standard deviation. $\mathrm{mmol} \mathrm{mol}^{-1}$, millimole per mole; \pm , plus or minus]

\begin{tabular}{ccc}
\hline Larval stage & Sr/Ca mmol mol $^{-1} \pm$ standard deviation & Mg/Ca mmol mol ${ }^{-1} \pm$ standard deviation \\
\hline III & $5.916 \pm 0.161$ & $218.275 \pm 59.957$ \\
V & $6.11 \pm 0.300$ & $267.081 \pm 67.211$ \\
Chitinous matrix standard & $5.571 \pm 0.007$ & $138.389 \pm 1.473$ \\
\hline
\end{tabular}




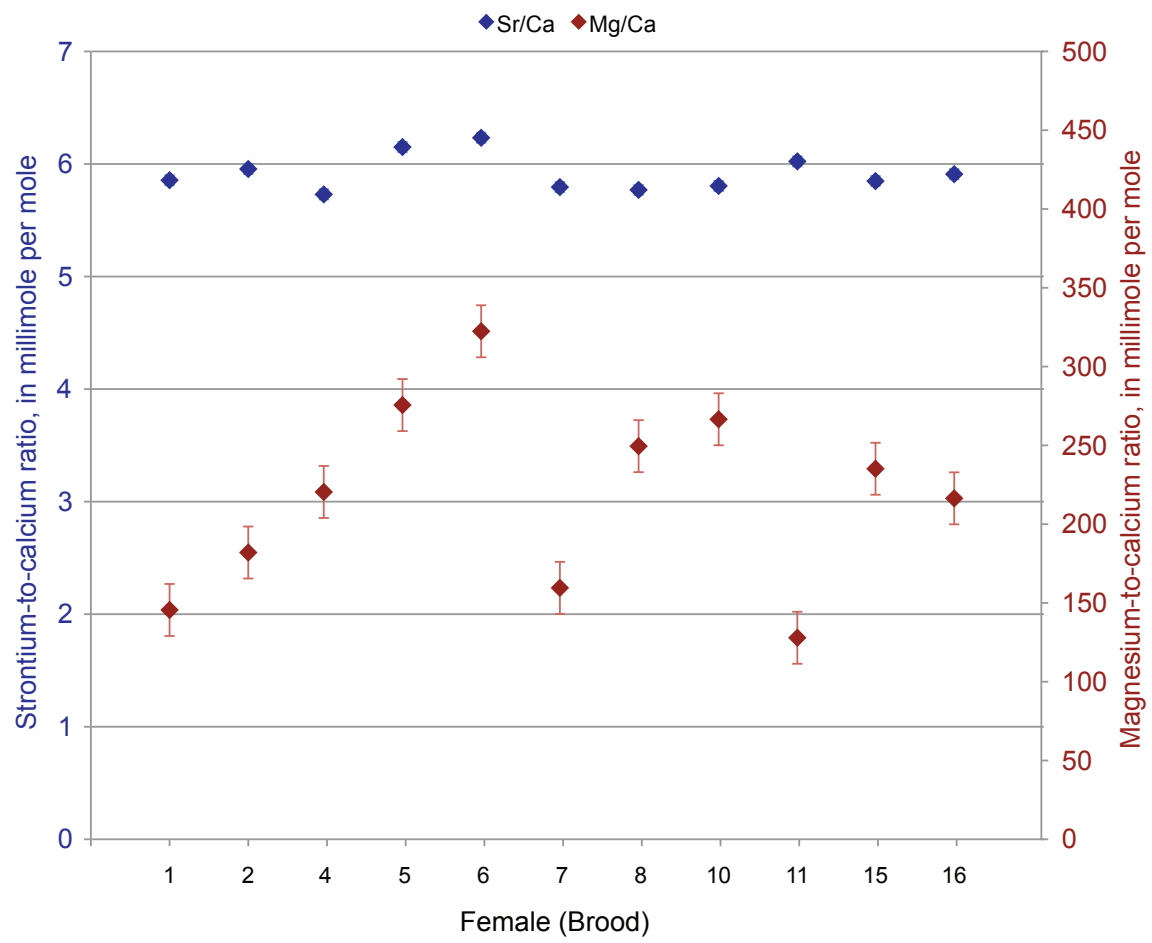

Figure 3. Strontium-to-calcium ( $\mathrm{Sr} / \mathrm{Ca}$; blue) and magnesium-to-calcium (Mg/Ca; red) ratios for stage III stone crab larvae from 11 different broods raised at 30 degrees Celsius and 37 practical salinity units. Each sample contained 50 individuals. Error bars represent standard error of the mean. Error is so small in Sr/Ca that error bars are obscured by the symbols marking data points.

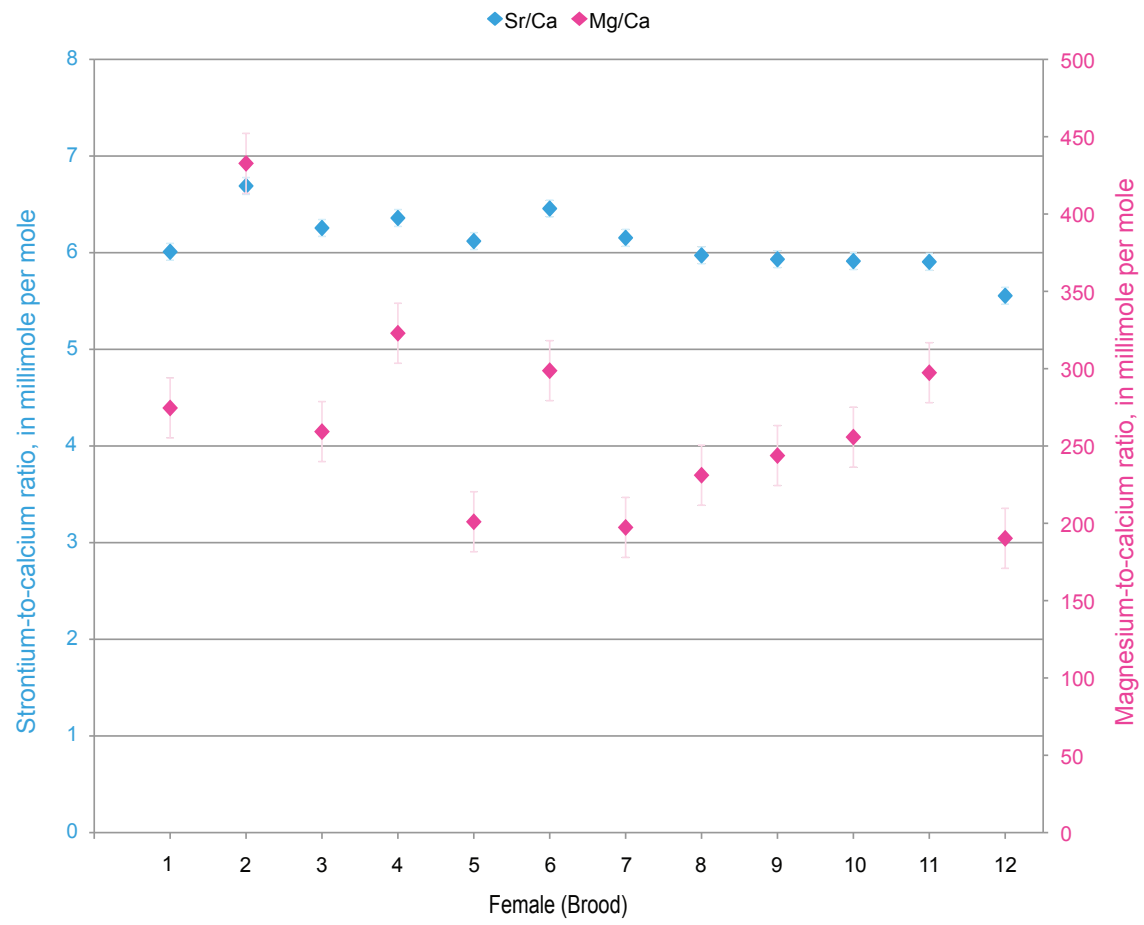

Figure 4. Strontium-to-calcium (Sr/Ca; light blue) and magnesium-to-calcium (Mg/Ca; pink) ratios for stage $V$ stone crab larvae from 12 different broods raised at 30 degrees Celsius and 37 practical salinity units. Each sample contained 10 individuals. Error bars represent standard error of the mean. Error is so small in $\mathrm{Sr} / \mathrm{Ca}$ that error bars are obscured by the symbols marking data points. 


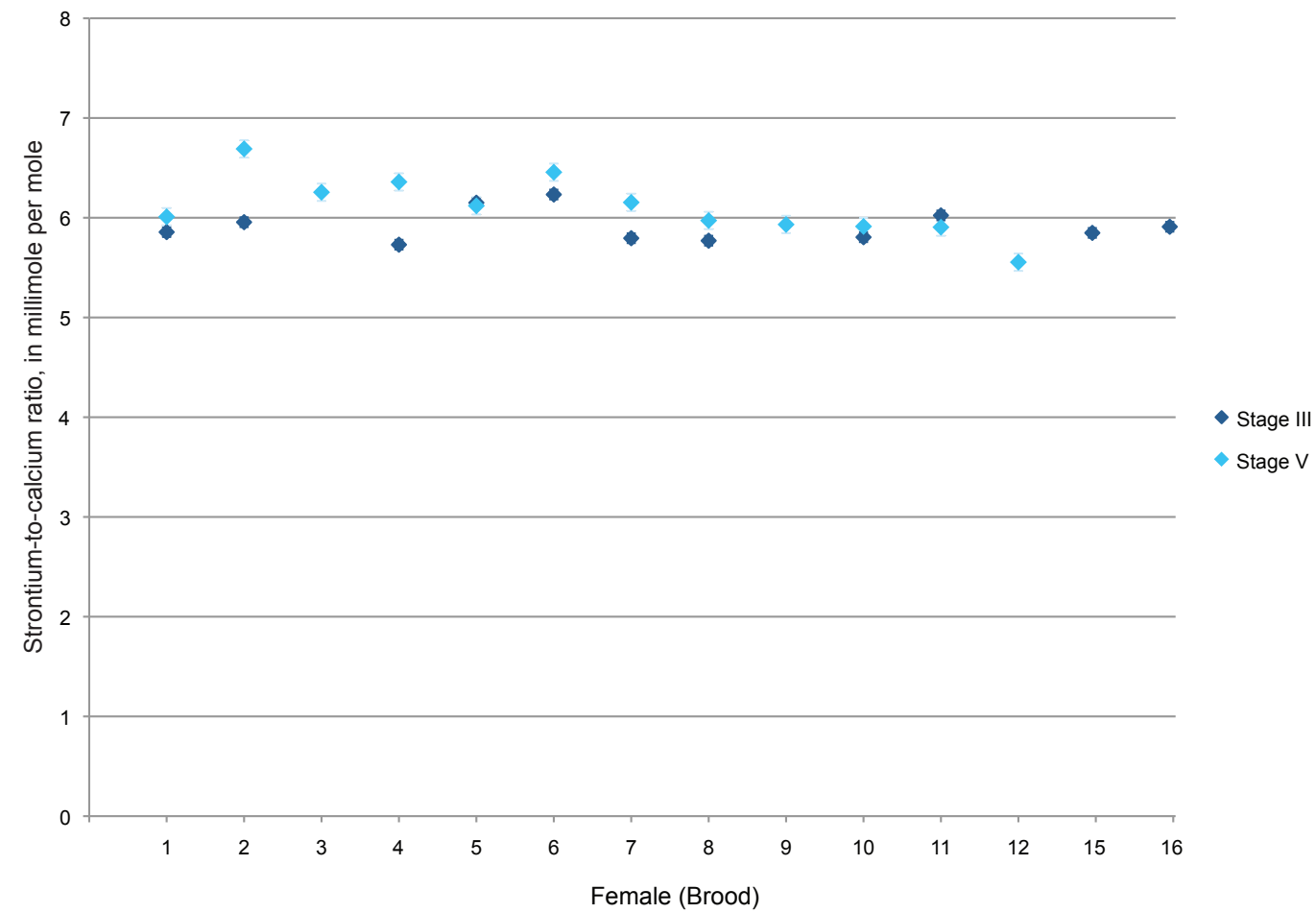

Figure 5. Strontium-to-calcium ( $\mathrm{Sr} / \mathrm{Ca}$ ) ratios for stone crab larval stage III (dark blue) and stage $\mathrm{V}$ (light blue). Error bars represent standard error of the mean. Error is so small in $\mathrm{Sr} / \mathrm{Ca}$ that error bars are obscured by the symbols marking data points.

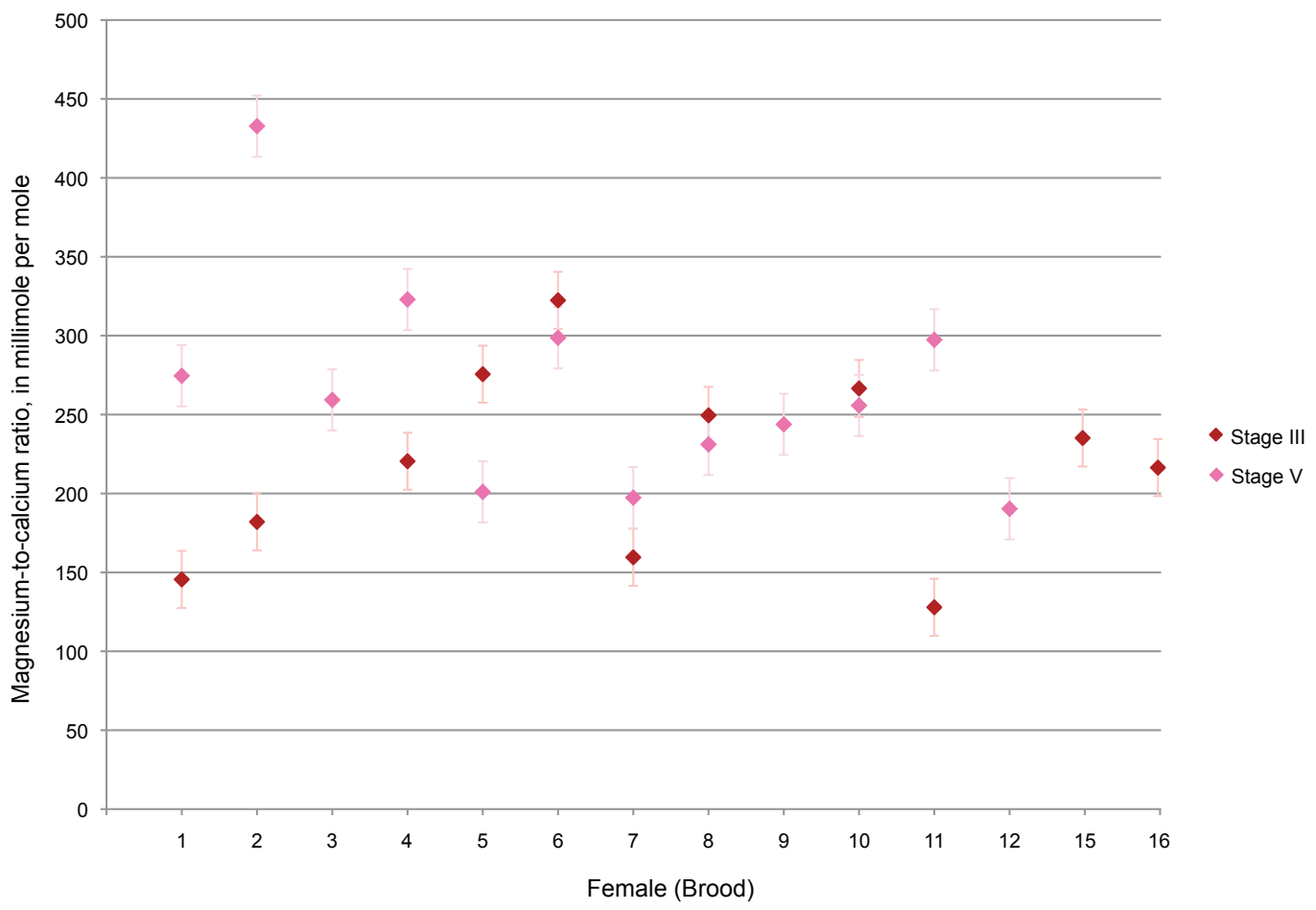

Figure 6. Magnesium-to-calcium $(\mathrm{Mg} / \mathrm{Ca}$ ) ratios for stone crab larval stage III (red) and stage $\mathrm{V}$ (pink). Error bars represent standard error of the mean. 


\section{Conclusions}

The method used in this study provided credible estimates of trace $\mathrm{Sr} / \mathrm{Ca}$ and $\mathrm{Mg} / \mathrm{Ca}$ ratios in the larval exoskeletons of $M$. mercenaria, demonstrating that ICP-OES can be used to determine the trace-metal composition of chitinous organisms like the Florida stone crab. We demonstrated that these methods could be used to measure trace elements in field-collected larvae. No field data exist on the larval dispersal and migration patterns of stone crabs, which is surprising considering the importance of the commercial fishery. Trace-element ratios in larval exoskeletons could, therefore, be used as a management tool for identifying potential source-sink populations/habitats and determining larval trajectories (that is, correlating larval signatures with environmental signatures to help describe dispersal in the field).

We found that there was a significant difference in the concentration of $\mathrm{Sr} / \mathrm{Ca}$ between stage III and stage $\mathrm{V}$ stone crab larvae, but the difference in $\mathrm{Mg} / \mathrm{Ca}$ was not significant. The difference in the $\mathrm{Sr} / \mathrm{Ca}$ and $\mathrm{Mg} / \mathrm{Ca}$ ratios between the stone crab larvae and the matrix standard (adult crab) suggests that ontogenetic shifts may also occur over longer periods in the life history of these crustaceans. Additionally, our results showed that there was a high degree of variability among broods of stone crab larvae. Future work could attempt to determine the magnitude and causes of among-brood variability, including the potential influence of the brooding female, on the elemental composition of stone crab larvae.

This study lays the groundwork for future research such as focusing on the skeletal composition of larval stone crabs throughout ontogeny when exposed to multiple stressors such as elevated partial pressure of carbon dioxide $\left(\mathrm{CCO}_{2}\right)$ levels and temperature. Changes in the skeletal composition during exposure to elevated $p \mathrm{CO}_{2}$ and temperature could make larvae more susceptible to predation or affect larval swimming behaviors that mediate vertical positioning in the water column. These changes could ultimately affect larval transport and the sustainability of future stone crab populations. 


\section{References Cited}

Anastasia, J.R., Morgan, S.G., and Fisher, N.S., 1998, Tagging crustacean larvae-Assimilation and retention of trace elements: Limnology and Oceanography, v. 43, no. 2, p. 362-368, accessed January 2016 at https://doi.org/10.4319/1o.1998.43.2.0362.

Darrenougue, Nicolas, De Deckker, Patrick, Eggins, Stephen, and Payri, Claude, 2014, Sea-surface temperature reconstruction from trace elements variations of tropical coralline red algae: Quaternary Science Reviews, v. 93, p. 34-46, accessed January 2016 at https://doi.org/10.1016/j.quascirev.2014.03.005.

DeLong, K.L., Flannery, J.A., Maupin, C.R., Poore, R.Z., and Quinn, T.M., 2011, A coral Sr/Ca calibration and replication study of two massive corals from the Gulf of Mexico, Palaeogeography, Palaeoclimatology, Palaeoecology, v. 307, p. 117-128, accessed January 2016 at https://doi.org/10.1016/j.palaeo.2011.05.005.

DiBacco, Claudio, and Levin, L.A., 2000, Development and application of elemental fingerprinting to track the dispersal of marine invertebrate larvae: Limnology and Oceanography, v. 45, no. 4, p. 871-880, accessed January 2016 at https://doi.org/10.4319/lo.2000.45.4.0871.

Edgar, K.M., Anagnostou, E., Pearson, P.N., and Foster, G.L., 2015, Assessing the impact of diagenesis on $\delta^{11} \mathrm{~B}, \delta^{13} \mathrm{C}, \delta^{18} \mathrm{O}, \mathrm{Sr} / \mathrm{Ca}$ and $\mathrm{B} / \mathrm{Ca}$ values in fossil planktic foraminiferal calcite: Geochimica et Cosmochimica Acta, v. 166, p. 189-209, accessed January 2016 at https://doi.org/10.1016/j.gca.2015.06.018.

Flannery, J.A., and Poore, R.Z., 2013, Sr/Ca proxy sea-surface temperature reconstructions from modern and Holocene Montastraea faveolata specimens from the Dry Tortugas National Park, Florida, U.S.A., in Brock, J.C., Barras, J.A., and Williams, S.J., eds., Understanding and predicting change in the coastal ecosystems of the northern Gulf of Mexico: Journal of Coastal Research, Special Issue 63, p. 20-31, accessed January 2016 at https://doi.org/10.2112/SI63-003.1.

Flannery, J.A., Richey, J.N., Thirumalai, Kaustubh, Poore, R.Z., and DeLong, K.L., 2017, Multi-species coral $\mathrm{Sr} / \mathrm{Ca}$-based sea-surface temperature reconstruction using Orbicella faveolata and Siderastrea siderea from the Florida Straits: Palaeogeography, Palaeoclimatology, Palaeoecology, v. 466, p. 100-109, accessed November 2016 at https://doi.org/10.1016/j.palaeo.2016.10.022.

Florida Fish and Wildlife Conservation Commission, undated, Commercial fisheries landings summaries, accessed July 2015 at https://public.myfwc.com/FWRI/PFDM/ReportCreator.aspx.

Gamboa, G., Halfar, J., Hetzinger, S., Adey, W., Zack, T., Kunz, B., and Jacob, D.E., 2010, Mg/Ca ratios in coralline algae record northwest Atlantic temperature variations and North Atlantic Oscillation relationships: Journal of Geophysical Research, v. 115, C12044, accessed January 2016 at https://doi.org/10.1029/2010JC006262.

Krimsky, L.S., Gravinese, P.M., Tankersley, R.A., and Epifanio, C.E., 2009, Patterns of larval release in the Florida stone crab, Menippe mercenaria: Journal of Experimental Marine Biology and Ecology, v. 373, p. 96-101, accessed January 2016 at https://doi.org/10.1016/j.jembe.2009.03.013.

Mootz, C.A., and Epifanio, C.E., 1974, An energy budget for Menippe mercenaria larvae fed Artemia nauplii: Biological Bulletin, v. 146, no. 1, p. 44-55, accessed January 2016 at https://doi.org/10.2307/1540396.

Porter, H.J., 1960, Zoeal stages of the stone crab, Menippe mercenaria Say: Chesapeake Science, v. 1, p. 168-177, accessed January 2016 at https://doi.org/10.2307/1350394.

Richey, J.N., Poore, R.Z., Flower, B.P., and Quinn, T.M., 2007, 1400 yr multiproxy record of climate variability from the northern Gulf of Mexico: Geology, v. 35, no. 5, p. 423-426, accessed January 2016 at https://doi.org/10.1130/G23507A.1. 
Ries, J.B., 2011, Skeletal mineralogy in a high- $\mathrm{CO}_{2}$ world: Journal of Experimental Marine Biology and Ecology, v. 403, p. 54-64, accessed January 2016 at https://doi.org/10.1016/j.jembe.2011.04.006.

Ries, J.B., Cohen, A.L., and McCorkle, D.C., 2009, Marine calcifiers exhibit mixed responses to $\mathrm{CO}_{2}-$ induced ocean acidification: Geology, v. 37, no. 12, p. 1131-1134, accessed January 2016 at https://doi.org/10.1130/G30210A.1.

Russell, A.D., Honisch, B., Spero, H.J., and Lea, D.W., 2004, Effects of seawater carbonate ion concentration and temperature on shell $\mathrm{U}, \mathrm{Mg}$, and $\mathrm{Sr}$ in cultured planktonic foraminifera: Geochimica Et Cosmochimica Acta, v. 68, no. 21, p. 4347-4361, accessed January 2016 at https://doi.org/10.1016/j.gca.2004.03.013.

Schrag, D.P., 1999, Rapid analysis of high-precision $\mathrm{Sr} / \mathrm{Ca}$ ratios in corals and other marine carbonates: Paleoceanography, v. 14, no. 2, p. 97-102, accessed January 2016 at https://doi.org/10.1029/1998PA900025.

Sulkin, S.D., 1984, Behavioral basis of depth regulation in the larvae of brachyuran crabs: Marine Ecology Progress Series, v. 15, p. 181-205, accessed January 2016 at http://www.int-res.com/articles/meps/15/m015p181.pdf

Whiteley, N.M., 2011, Physiological and ecological responses of crustaceans to ocean acidification: Marine Ecology Progress Series, v. 430, p. 257-271, accessed January 2016 at https://doi.org/10.3354/meps09185.

Williams, B., Halfar, J., DeLong, K.L., Hetzinger, S., Steneck, R.S., and Jacob, D.E., 2014, Multi-specimen and multi-site calibration of Aleutian coralline algal $\mathrm{Mg} / \mathrm{Ca}$ to sea surface temperature: Geochimica Et Cosmochimica Acta, v. 139, p. 190-204, accessed January 2016 at https://doi.org/10.1016/j.gca.2014.04.006.

Wu, H.C., Linsley, B.K., Dassié, E.P., Schiraldi, Benedetto, Jr., and deMenocal, P.B., 2013, Oceanographic variability in the South Pacific Convergence Zone region over the last 210 years from multi-site coral Sr/Ca records: Geochemistry, Geophysics, Geosystems, v. 14, no. 5, p. 1435-1453, accessed January 2016 at https://doi.org/10.1029/2012GC004293. 


\section{Appendix}

Florida stone crab (Menippe mercenaria) larval trace-metal data.

[Sr/Ca, strontium-to-calcium ratio; $\mathrm{Mg} / \mathrm{Ca}$, magnesium-to-calcium ration; $\mathrm{mmol} \mathrm{mol}{ }^{-1}$, millimole per mole]

\begin{tabular}{l|c|c|c}
\hline Brood & Stage & Sr/Ca $\left(\mathrm{mmol} \mathrm{mol}^{-1}\right)$ & $\mathrm{Mg} / \mathrm{Ca}\left(\mathrm{mmol} \mathrm{mol}^{-1}\right)$ \\
\hline F1 & III & 5.856 & 145.540 \\
F2 & III & 5.956 & 182.001 \\
F4 & III & 5.730 & 220.434 \\
F5 & III & 6.150 & 275.597 \\
F6 & III & 6.233 & 322.400 \\
F7 & III & 5.795 & 159.566 \\
F8 & III & 5.770 & 249.495 \\
F10 & III & 5.805 & 266.556 \\
F11 & III & 6.023 & 127.893 \\
F15 & III & 5.848 & 235.156 \\
F16 & III & 5.910 & 216.384 \\
F1 & V & 6.009 & 274.591 \\
F2 & V & 6.691 & 432.760 \\
F3 & V & 6.256 & 259.305 \\
F4 & V & 6.359 & 322.922 \\
F5 & V & 6.120 & 200.995 \\
F6 & V & 6.457 & 298.697 \\
F7 & V & 6.154 & 197.350 \\
F8 & V & 5.972 & 231.113 \\
F9 & V & 5.932 & 243.803 \\
F10 & V & 5.913 & 255.762 \\
F11 & V & 5.905 & 297.372 \\
F12 & V & 5.555 & 190.304 \\
\hline
\end{tabular}


m웅

공

음.

क

유 줌

홍

율 응

万ิ응

$1 ?$

䍡

1

욤

끄 ๙

끼일

용 혹

N.

के

$\overrightarrow{\vec{A}}$

옷

$\frac{\frac{1}{0}}{0}$

음

끙.

os

옹

$\stackrel{\bigcirc}{\frac{9}{9}}$



옹.

క్త

胥.

.

ఖ্ণ

돌.

$\bar{F}$

产.

$\stackrel{\Phi}{\curvearrowright}$

등

离 